\title{
Haemoglobin E/Beta Thalassaemia- A Study in BSMMU
}

\author{
Md Abdul Aziz ${ }^{1}$, Masuda Begum², Md. Sirajul Islam³ , Naima Islam4, Md Jalilur Rahman5, Amin Lutful Kabir ${ }^{1}$ \\ ${ }^{1}$ Assistant Professor, ${ }^{2}$ Associate professor, ${ }^{5}$ Professor, Chairman, Department of Haematology, BSMMU, ${ }^{3}$ Assistant Professor Department \\ of Haematology, Dhaka Medical College, ${ }^{4}$ Assistant Professor Department of Haematology, National Institute of Cancer Hospital, \\ Mohakhali,Dhaka.
}

\begin{abstract}
Background: Thalassaemias and haemoglobinopathies have been found sporadically in every ethnic group and geographic region, they occur with particularly high frequency from the shores of the Mediterranean and Africa through the Middle East, the Indian subcontinent, Burma and Southeast Asia. Objective: The study was designed to find out the incidence of $\mathrm{HbE}$ /beta thalassaemia in BSMMU. Method: A total of 700 patients suspected to have been suffering from haemolytic anaemia were included in the study. Patients having evidence of haemolysis in peripheral blood film were selected for reticulocyte count and haemoglobin electrophoresis in cellulose acetate membrane at $\mathrm{p}^{\mathrm{H}}$ 8.6. Result: The study group of 700 patients underwent Hb-electrophoresis of which only 52 (7.4\%) cases were diagnosed as HbE/beta thalassaemia. Out of 52 cases, 34 (65.4\%) patients were found symptomatic and the remaining 18 (34.6\%) patients were asymptomatic. Out of 34 symptomatic cases of $\mathrm{HbE} /$ beta thalassaemia, only 14 cases needed blood transfusion. Among the 14 patients, only 8 patients needed more than 10 units of transfusion and 6 patients needed frequent transfusion that is two units of blood in every month. Conclusion: It is clearly evident from the present and other studied so far carried out in this Indian subcontinent and South-East Asia that hereditary haemolytic anaemia due to globin chain defects are quite common in this region, especially in Bangladesh and are responsible for considerable morbidity and mortality.
\end{abstract}

Key words: Thalassaemia; Haemoglobinopathies; HbE/beta thalassemia.

[BSMMU J 2009; 2(2): 78-80]

\section{Introduction:}

The inherited diseases of haemoglobin are the most common single gene disorders. With global improvement in childhood diseases thalassaemia will become a major health issue in millennium. The beta - thalassaemia is the most common type of thalassaemia because they are so common, occur widely in a broad belt ranging from Mediterranean and parts of North and West Africa through the Middle East, Bangladesh, India, Sri Lanka, Thailand and other countries of South East Asia ${ }^{1}$.

The hereditary disorders of haemoglobin are classified into two broad groups, the thalassaemias and haemoglobinopathies. The haemoglobinopathies are characterized by the production of structurally defective haemoglobin due to abnormalities in the formation of the globin moiety of the molecule. The thalassaemias are characterized by a reduced rate of production of normal haemoglobin due to absent or decreased synthesis of one or more types of normal globin polypeptide chains ${ }^{2}$. Among more than 300 structural variants, $\mathrm{Hb} \mathrm{E}$ is the second most prevalent haemoglobin disorder in the world.

Address for Correspondence: Dr Md. Abdul Aziz, Assistant Professor, Department of Haematology, BSMMU, Shahabag, Dhaka, Email: aziz fcps@yahoo.com
Haemoglobin $\mathrm{E}$ is quite common in Bangladesh and has a worldwide carrier of 53 millions ${ }^{1}$. These may occur due to continued migration of population from one area to another.

The carrier of beta-thalassaemia trait is reported to be more than 100 millions world wide ${ }^{3}$.

In Bangladesh inherited haemoglobin disorders is quite common but no definitive data regarding incidence of $\mathrm{HbE}$ / beta thalassaemia. The aim of the study is to find out the incidence of $\mathrm{HbE} /$ beta thalassaemia in BSMMU.

\section{Methods:}

This study was carried out in the department of Haematology, BSMMU from January 2002 to December 2002. A total of 700 patients of both sex, suspected to have been suffering from haemolytic anaemia were included in the study. Patients under 16 years of age, and who were taking hydroxyurea and cytarabine were excluded from the study.

Two ml venous blood was taken from each patient under aseptic precautions and collected into EDTA bottles for the estimation of haemoglobin concentration, complete blood count with red cell morphology in peripheral blood film stained by Leishman's stain. Patients with evidence of haemolytic feature in blood film were selected for 
reticulocytes count and haemoglobin electrophoresis in cellulose acetate membrane at $\mathrm{p}^{\mathrm{H}}$ 8.6.

52 patients diagnosed as $\mathrm{HbE} /$ beta thalassaemia, were selected for the study population. They were thoroughly interviewed regarding the age at presentation, family history, presenting symptoms with duration of illness and blood transfusion requirement.

Statistical Analysis was done using the SPSS 11.5. Results were tested for level of significant using non-parametric Chi-square (c2) test. ' $\mathrm{P}$ ' value of $<0.05$ was considered as to be statistically significant at the level of 95\% CI.

\section{Results:}

Among the 700 cases only 52 cases (7.4\%) were diagnosed as $\mathrm{HbE} /$ beta thalassaemia.

The mean \pm SD with range of age of the study subjects was $24.8 \pm 6.1$ with $16-48$ yrs. Out of 52 patients 28 were male (53.8\%) and 24 female (46.2\%) with a male: female ratio $1.17: 1$ as shown in table $\mathrm{I}$.

Table I

Sex distribution of the HbE/Beta thalassaemia subjects $(n=52)$

\begin{tabular}{lccc}
\hline Sex & Frequency & Percent & Ratio \\
\hline Male & 28 & 53.8 & Male: female1.17:1 \\
Female & 24 & 46.2 & \\
\hline Total & 52 & 100.0 & \\
\hline
\end{tabular}

34 (65.4\%) patients were symptomatic and the rest (34.6\%) asymptomatic with statistical significance $(p=0.027)$. The symptomatic patients presented with different symptoms as shown in Table- II.

Table II

Distribution of patients by Clinical presentation of $\mathrm{HbE} /$ Beta thalassaemia subjects $(n=52)$

\begin{tabular}{lccc}
\hline $\begin{array}{l}\text { Clinical } \\
\text { presentation }\end{array}$ & $\begin{array}{c}\text { No. of } \\
\text { patients }\end{array}$ & Percentage & $P$-value \\
\hline Asymptomatic & 18 & 34.6 & $0.027^{*}$ \\
Symptomatic & 34 & 65.4 & \\
$\quad$ Weakness & 30 & 88.2 & \\
$\quad$ Pallor & 22 & 64.7 & \\
$\quad$ Palpitation & 14 & 41.2 & \\
Jaundice & 11 & 32.4 & \\
Abdominal lump & 06 & 17.4 & \\
\hline
\end{tabular}

$*=\mathrm{p}<0.05$
On the basis of haemoglobin level 9 patients (17.3\%) had severe anaemia ( $\mathrm{Hb}<6 \mathrm{gm} / \mathrm{dl}$ ), 24 (46.2\%) moderate anaemia (Hb 6-10 gm/dl) and 19 (36.5\%) mild anaemia ( $\mathrm{Hb}>10 \mathrm{gm} /$ $\mathrm{dl}$ ) with statistical significance ( $\mathrm{p}=0.035$ ) as shown in table III.

\section{Table III}

Distribution of Patients by Severity of anaemia of $\mathrm{HbE} /$ Beta thalassaemia $(n=52)$

\begin{tabular}{lccc}
\hline $\begin{array}{l}\text { Group } \\
(\text { Hb: gmldl) }\end{array}$ & $\begin{array}{c}\text { No. of } \\
\text { patients }\end{array}$ & Percentage & $\begin{array}{c}P \text { - } \\
\text { value }\end{array}$ \\
\hline Severe $(<6)$ & 09 & 17.3 & 0.035 \\
Moderately severe (6-10) & 24 & 46.2 & \\
Mild $(>10)$ & 19 & & 36.5 \\
\hline
\end{tabular}

Of the symptomatic cases, 13 patients (38.2\%) needed red cell transfusion (transfusion dependant) and 21 (61.8\%) did not ( transfusion independent) without statistical significance $(\mathrm{p}=0.17)$ as shown in table IV.

Table IV

Distribution of Patients by Transfusion dependence of $\mathrm{HbE} /$ Beta thalassaemia $(n=34)$

\begin{tabular}{lccc}
\hline $\begin{array}{l}\text { Blood } \\
\text { transfusion }\end{array}$ & $\begin{array}{c}\text { No. of } \\
\text { needed }\end{array}$ & $\begin{array}{c}\text { Percentage } \\
\text { patients }\end{array}$ & $\begin{array}{c}P \text { - } \\
\text { value }\end{array}$ \\
\hline Yes & 13 & 38.2 & 0.17 \\
No & 21 & 61.8 & \\
\hline
\end{tabular}

\section{Discussion:}

The incidence of hereditary haemolytic anaemia in Bangladesh is not known. However, the data regarding the incidence of hereditary haemolytic anaemia in some of our neighbouring countries is available. In India, the highest incidence of $\mathrm{HbE}$ trait has been reported from West Bengal (3.9\%), and it is also prevalent in Assam and Tripura states ${ }^{4,5}$. HbE/beta-thalassaemia is the commonest of the thalassaemia syndrome in Myanmar ${ }^{7}$. Bangladesh is in geographical continuity with West Bengal, Assam, Tripura states of India and with Myanmar. The population in West Bengal shares the common ethnic ancestry with the people of our country.

Out of 700 patients taken initially in this study, only 52 cases of $\mathrm{HbE} / \mathrm{beta}$-thalassaemia were found which constitutes 7.4\%; and the rest 648 cases (92.6\%) including beta- thalassaemia trait, $\mathrm{HbE}$ disease, $\mathrm{HbE}$ trait and also normal persons were not included in this study. This figure 
slightly differs from another study ${ }^{6}$ where the frequency of $\mathrm{HbE} /$ beta-thalassaemia was $12.1 \%$. This difference between the two studies may be due to exclusion of pediatric populations in the present study.

Examination of haemoglobin level in hereditary haemoglobin disorders is a very good indicator of measurement of severity of the disease. Other important parameters for determining the severity of the disease are the severity of sign and symptoms of anaemia. In this present study among the 52 patients only 34 patients were symptomatic and 18 patients asymptomatic. Among all, 9 patients (17.3\%) were severely anaemic, 24 (46.2\%) patients moderately anaemic and the rest 19 (36.5\%) were only mildly anaemic $(\mathrm{Hb}>10 \mathrm{~g} / \mathrm{dl})$. These findings are similar to the findings in United Kingdom ${ }^{1}$. Exactly the same types of findings were noted by Aung - Thang - Batu et $\mathrm{al}^{7}$. They also concluded that $\mathrm{HbE} /$ beta-thalassaemia is the commonest of the thalassaemia syndromes presenting with symptoms of anaemia in Myanmar.

Another parameter of measurement of severity of the disease is transfusion dependency and frequency of transfusion. Prawse Wasi and his co-workers have systematically investigated the determinants for different degrees of severity of anaemia in this group of patients. They concluded that concomitant inheritance of an alphathalassaemia 1 gene leading to elevated HbF level responsible for the severity of anaemia ${ }^{8,9}$.

\section{Conclusion:}

It is clearly evident from the present and other studied so far carried out in this Indian subcontinent and South-East Asia that hereditary haemolytic anaemia due to globin chain defects are quite common in this region, especially in Bangladesh and are responsible for considerable morbidity and significant mortality. These are the diseases mainly of paediatric groups, adolescents and young adults.
Both genders are equally affected. Haemoglobinopathies, particularly $\mathrm{HbE}$ and beta-thalassaemia are prevalent in this country. When $\mathrm{HbE}$ co-exists with beta-thalassaemia in the same individual, severe anaemia is manifested. The large numbers of asymptomatic patients is also hidden among the apparent normal population and are the real threat to our future generation because of the possibility of homozygous or double heterozygous inheritance or silent spread of traits through marriage.

\section{References:}

1. Weatherall DJ. Hemoglobin and Inherited Disorders of Globin Synthesis. In A.V. Hoffbrand, Lewis MS, Tuddenham, editors. Postgraduate Haematology $5^{\text {th }}$ ed. Oxford: Butterworth Henimann 2005; p85 -103.

2. Firkin F, Chesterman C, Penington D, Rush B. de Gruchy,s clinical haematology in medical practice, ${ }^{\text {5th }}$ edition, 1989, 7: $137-171$.

3. Bessmann JD, Fein Stein DI. Quantitative anisocytosis as a discriminant between iron deficiency and thalassaemia. Blood 1979. 53: 288.

4. Gupta SC, Methrota TN, Methrota VG. Haemoglobin EThalassaemia in Uttar Pradesh. Indian J of Medical Res 1970; 58: $857-862$.

5. Mitra SS, Kambo BS. Frequency of febrile illness in HbEthalassaemia patient. . Indian J of Medical Res 1984; 79 : 779 $-82$.

6. Haque MS, Alam MA, Khan Wa, Amin SK, Banu B, Hossain et al. Thalassaemia situation in Dhaka Shishu Hospital. DS (Child) HJ 1999; 15: 30 - 36.

7. Michael EJ Beard, Thomas F, Necheles and Donald M. Allen. Intensive Transfusion Therapy in Thalassaemia Major. Paediatrics 1967; 40: 911-915

8. Higgs. DR, Vickers.M.A, Wilkie AO, Pretorious IM, Jarman AP and Weatherall DJ. A review of molecular genetics of the human $\alpha$-globin gene cluster. Blood, 1989; 73: 1081-1104.

9. Was P, Poortrakul P, Fucharoen S, Winichagoon P, Wilairant P, Proomboon A. Thalassaemia in South - East Asia; determination of different degree of severity of anaemia in thalassaemia. Ann NY Acad Sci 1985; 445: 119. 